Barati, R., Johnson, S. J., McCool, S., Green, D. W., Willhite, G. P. and Liang, J.-T. (2012), Polyelectrolyte complex nanoparticles for protection and delayed release of enzymes in alkaline $\mathrm{pH}$ and at elevated temperature during hydraulic fracturing of oil wells. J. Appl. Polym. Sci.. Publisher's official version: <http://dx.doi.org10.1002/app.36845>. Open Access version: http://kuscholarworks.ku.edu/dspace/.

[This document contains the author's accepted manuscript. For the publisher's version, see the link in the header of this document.]

Paper citation: Barati, R., Johnson, S. J., McCool, S., Green, D. W., Willhite, G. P. and Liang, J.-T. (2012), Polyelectrolyte complex nanoparticles for protection and delayed release of enzymes in alkaline $\mathrm{pH}$ and at elevated temperature during hydraulic fracturing of oil wells. J. Appl. Polym. Sci..

doi: 10.1002/app.36845

Keywords: gels; nanoparticle; enzymes; polyelectrolytes; fracturing fluids; guar; hydraulic fracture cleanup

Abstract: Polyethylenimine-dextran sulfate polyelectrolyte complexes (PEC) were used to entrap two enzymes used to degrade polymer gels following hydraulic fracturing of oil wells in order to obtain delayed release and to protect the enzyme from harsh conditions. Degradation, as revealed by reduction in viscoelastic moduli, of borate-crosslinked hydroxypropyl guar gel by commercial enzyme loaded in polyelectrolyte nanoparticles was delayed up to 11 hours, compared to about three hours for equivalent systems where the enzyme mixture was not entrapped. PEC nanoparticles also protected both enzymes from denaturation at elevated temperature and $\mathrm{pH}$. 
Barati, R., Johnson, S. J., McCool, S., Green, D. W., Willhite, G. P. and Liang, J.-T. (2012), Polyelectrolyte complex nanoparticles for protection and delayed release of enzymes in alkaline $\mathrm{pH}$ and at elevated temperature during hydraulic fracturing of oil wells. J. Appl. Polym. Sci.. Publisher's official version: <http://dx.doi.org10.1002/app.36845>. Open Access version: http://kuscholarworks.ku.edu/dspace/.

\title{
Polyelectrolyte Complex Nanoparticles for Protection and Delayed Release of Enzymes in Alkaline pH and at Elevated Temperature during Hydraulic Fracturing of Oil Wells
}

\author{
Reza Barati, ${ }^{1}$ Stephen J. Johnson, ${ }^{2 *}$ Stan McCool, ${ }^{2}$ Don W. Green, ${ }^{1}$ G. Paul Willhite ${ }^{1}$ \& Jenn-Tai Liang ${ }^{1,2}$
}

${ }^{1}$ Department of Chemical \& Petroleum Engineering, The University of Kansas, Lawrence, KS 66045

${ }^{2}$ Tertiary Oil Recovery Project, The University of Kansas, Lawrence, KS 66045

*Corresponding author: sjohn@ku.edu

\begin{abstract}
Polyethylenimine-dextran sulfate polyelectrolyte complexes (PEC) were used to entrap two enzymes used to degrade polymer gels following hydraulic fracturing of oil wells in order to obtain delayed release and to protect the enzyme from harsh conditions. Degradation, as revealed by reduction in viscoelastic moduli, of borate-crosslinked hydroxypropyl guar gel by commercial enzyme loaded in polyelectrolyte nanoparticles was delayed up to 11 hours, compared to about three hours for equivalent systems where the enzyme mixture was not entrapped. PEC nanoparticles also protected both enzymes from denaturation at elevated temperature and $\mathrm{pH}$.
\end{abstract}

\section{Introduction}

Hydraulic fracturing of oil and gas production wells is often used to increase the available sand surface, and hence rate of fluid production. Fracturing fluids are injected under pressure to propagate a fracture into the reservoir, performing two main functions: (i) opening the fracture and (ii) transporting propping agents to maintain the fracture aperture after the pressure is released. ${ }^{1}$ Water-based fracturing fluids are preferred for economic, environmental and occupational health and safety reasons. Guar gum and derivatives such as hydroxypropyl guar (HPG) are commonly used to viscosify water in fracturing fluids for conventional treatments, though hydraulic fracturing in unconventional reservoirs is shifting towards lower viscosity "slick water" treatments. using polyacrylamides. ${ }^{2}$

The fracturing fluid must be highly viscous during the injection to minimize leak off of fluid and pressure into the surrounding matrix and to carry proppants effectively, and then "break" (degrade) to a water-like consistency to maintain high hydraulic conductivity in the fracture during subsequent production of hydrocarbons. Cross-linkers (e.g. borate) and breakers (either oxidizers or enzymes) are added to the fluid to fulfill each of these requirements. Enzymes have been used extensively to degrade both the fracturing fluid and the filter cake that forms on the faces of the fracture. ${ }^{3-5}$ Enzymes used as breakers of guar gels have several benefits over chemical oxidizers: they are relatively inexpensive especially considering that they are not consumed during their catalytic reaction with guar, they are environmentally benign, are easy to handle and are chemically compatible with surface equipment and tubing. ${ }^{1,3}$ However, enzymes become denatured and lose their catalytic activity at high temperature and 
Barati, R., Johnson, S. J., McCool, S., Green, D. W., Willhite, G. P. and Liang, J.-T. (2012), Polyelectrolyte complex nanoparticles for protection and delayed release of enzymes in alkaline $\mathrm{pH}$ and at elevated temperature during hydraulic fracturing of oil wells. J. Appl. Polym. Sci.. Publisher's official version: <http://dx.doi.org10.1002/app.36845>. Open Access version: http://kuscholarworks.ku.edu/dspace/.

extreme $\mathrm{pH}$ environments. ${ }^{3}$ Such conditions are often encountered in the field and this limits the application of enzymes as breakers for fracturing fluids.

The use of high concentrations of enzymes or oxidizers mixed with fracturing fluid to ensure degradation of the filter cake increases costs and causes premature degradation of the fluid and hence loss of viscosity during injection. Encapsulation techniques have been used to inactivate breakers during injection. However, the relatively large size of the capsules, which are usually designed to break open when the fracture recloses at the end of the injection, may result in incomplete degradation of filter cake. ${ }^{1,6}$ Polyethylenimine (PEI) - dextran sulfate (DS) PEC nanoparticles originally developed for drug delivery applications $s^{7-9}$ and adapted for oilfield applications ${ }^{10-12}$ were hypothesized to be capable of entrapping, releasing and protecting enzymes for fracturing fluids in a controlled manner. PECs are structures that form when aqueous solutions of polyanions and polycations are mixed together in nonstoichiometric ratios at low concentrations. Electrostatic attraction between oppositely charged polymers causes the polymers to self-assemble into particles and the excess charge on the outer surface contributes to their colloidal stability. If another charged entity is added during mixing of the polyelectrolytes, it may become incorporated into the particles where it is held by electrostatic and steric interactions. The size, charge, stability and entrapment efficiency of the PECs may be controlled by varying the molecular weight, charge density and relative concentrations of the polyelectrolytes, as well as the order of mixing of the various components, $\mathrm{pH}$, and shear. ${ }^{13}$ High entrapment efficiency of enzymes, homogeneous distribution and flexible release time are desired for this system to be potentially applied in breaking of fracturing fluids.

This study builds on our previous work on the application of PEC nanoparticles to entrap and release pectinase for fracturing fluids. ${ }^{10}$ Positively charged PEC nanoparticles were made by mixing the polyanion (DS) with excess (in terms of charge) polycation (PEI). Two enzymes with different temperature and $\mathrm{pH}$ optima used in the petroleum industry to break fracturing fluids were each entrapped in the PEC nanoparticles. A viscometric assay of the supernatant after centrifugation was used to calculate the entrapment efficiency (EE) for the nanoparticles loaded with enzymes. Order of mixing, concentration of enzymes and $\mathrm{pH}$ of the nanoparticle systems were varied to maximize EE of the two enzymes. Retardation of enzyme activity was observed by monitoring the viscoelastic moduli of borate-crosslinked guar and HPG gels over time. Degradation times were compared with controls using equivalent concentrations of unentrapped enzymes.

\section{Materials and Methods}

Materials: Chemicals were used as supplied: Sodium hydroxide, $1 \mathrm{~N}$ hydrochloric acid, dextran sulfate $\left(M_{w}=500 \mathrm{kDa}\right)$, polyethylenimine $\left(M_{w}=25 \mathrm{kDa}\right)$, sodium thiosulfate pentahydrate, potassium chloride and sodium hydrate (Fisher Scientific, Pittsburgh, PA); sodium borate (J.T. Baker Chemical Co., Phillipsburg, NJ); hydroxypropyl guar (HPG) gum blend (Jaguar ${ }^{\circledR} 415$, Rhodia, Paris, France); pectinase from Aspergillus aculaceatus (Sigma-Aldrich, St. Louis, MO) and Econo Gelbreak-EL2X (Economy Polymers and Chemicals, Houston, TX) - enzyme activities of $100 \%$ were assumed for concentration calculations. 
Barati, R., Johnson, S. J., McCool, S., Green, D. W., Willhite, G. P. and Liang, J.-T. (2012), Polyelectrolyte complex nanoparticles for protection and delayed release of enzymes in alkaline $\mathrm{pH}$ and at elevated temperature during hydraulic fracturing of oil wells. J. Appl. Polym. Sci.. Publisher's official version: <http://dx.doi.org10.1002/app.36845>. Open Access version: http://kuscholarworks.ku.edu/dspace/.

Preparation of Polyelectrolyte Complex Nanoparticles: Nanoparticles were made using the method presented previously. ${ }^{10}$ In a typical formulation, $1 \mathrm{~mL}$ of a $1 \% \mathrm{w} / \mathrm{w}$ aqueous solution of DS ( $\mathrm{pH}=7.8)$ was pipetted rapidly into $2 \mathrm{~mL}$ of a $1 \% \mathrm{w} / \mathrm{w}$ aqueous solution of $\mathrm{PEI}(\mathrm{pH}$ adjusted to 8.0 using $4 \mathrm{~N} \mathrm{HCl}$ ) while stirring. The solution was then stirred for 20 minutes at $600 \mathrm{rpm}$. Enzymes were added rapidly from a $100 \mu \mathrm{L}$ pipette as $0.1 \mathrm{~mL}$ of a $25 \% \mathrm{w} / \mathrm{w}$ pectinase solution or $0.1 \mathrm{~mL}$ of EL2X solution either before or after the DS (Table 1). Enzyme-loaded nanoparticles were used as a breaker in polymer systems at a final concentration of $0.1 \% \mathrm{w} / \mathrm{w}$ pectinase or $0.4 \% \mathrm{EL} 2 \mathrm{X}$.

\section{Size and Zeta Potential Measurement of Polyelectrolyte Complex} Nanoparticles: A ZetaPALS zeta potential analyzer (Brookhaven Instruments Corp., Long Island, NY) was used to measure the mean particle size of nanoparticles in samples diluted approximately $40 \times$ by volume with deionized water. Zeta potential was also measured by phase analysis light scattering using the same instrument using samples diluted approximately $20 \times$ with $1.0 \mathrm{mM} \mathrm{KCl}$ solution. Zeta potential was estimated using the Smoluchowski approximation from the previously measured size and the electrophoretic mobility of the nanoparticles. ${ }^{14}$

\section{Determination of Enzyme Activity and Entrapment Efficiency: Entrapment} efficiency (EE) of the enzyme in the PEC nanoparticles was determined by material balance (Eq. 1) using the total enzyme concentration in a sample $\left(C_{T}\right)$ and the enzyme concentration remaining in the supernatant of a centrifuged sample $\left(\mathrm{C}_{\mathrm{S})}\right.$. Enzyme concentrations in the sample and in the supernatant were determined by a procedure to measure the activity of the enzyme to degrade an HPG solution using viscosity measurements. The time for the viscosity of the solution to fall to $50 \%$ of its initial value $\left(t_{1 / 2}\right.$, hours) was used to calculate the activity of the enzyme after the method reported by Bell et al. (1955). ${ }^{15}$ Activity was defined as the reciprocal of $t_{1 / 2 .}$. Enzyme concentration was previously determined to be a proportional to the activity ${ }^{10}$ giving the relationship in Eq. 1 , in which $A_{T}=$ activity of unentrapped enzyme at concentration $C_{T}$, and $A_{S}=$ activity of supernatant.

$$
E E=\frac{C_{T}-C_{S}}{C_{T}} \times 100 \%=\frac{A_{T}-A_{S}}{A_{T}} \times 100 \%
$$

Eq. 1

Aqueous suspensions of PEC nanoparticles were centrifuged at $14,000 \mathrm{~g}$ for $1.5 \mathrm{~h}$ at $4{ }^{\circ} \mathrm{C}$ to produce the supernatant. To perform the viscometric assay for the total enzyme concentration, $2.0 \mathrm{~g}$ of 5000 ppm HPG solution was mixed at room temperature with an enzyme solution) to a total mass of $2.5 \mathrm{~g}$. Additions were calculated to give concentrations in the final mixture of $0.02 \%$ pectinase or $0.08 \%$ EL2X and $4000 \mathrm{ppm}$ HPG. The same procedure was used for the supernatants except the supernatants were 
Barati, R., Johnson, S. J., McCool, S., Green, D. W., Willhite, G. P. and Liang, J.-T. (2012), Polyelectrolyte complex nanoparticles for protection and delayed release of enzymes in alkaline $\mathrm{pH}$ and at elevated temperature during hydraulic fracturing of oil wells. J. Appl. Polym. Sci.. Publisher's official version: <http://dx.doi.org10.1002/app.36845>. Open Access version: http://kuscholarworks.ku.edu/dspace/.

diluted by the same factor as that used to control the concentration of enzyme of the nanoparticle suspensions before centrifugation. The enzyme-polymer mixtures $(1.5 \mathrm{~mL})$ were immediately placed in a Bohlin CS-10 rheometer (Malvern Instruments, Malvern, England) with a $40 \mathrm{~mm} / 4^{\circ}$ cone-and-plate geometry and the viscosity of the solution was measured over time as described below to determine $\mathrm{t}_{1 / 2}$. Where needed, polymer solution $\mathrm{pH}$ was adjusted using $1 \mathrm{M} \mathrm{NaOH}$. Experimental temperature and $\mathrm{pH}$ is reported in the figure legend for each experiment.

Preparation of HPG Solutions: Sufficient HPG to create a 5000 ppm solution was added slowly to the shoulder of a vortex of a vigorously $(600 \mathrm{rpm})$ stirred solution of $2 \% \mathrm{KCl}$ and $1.35 \mathrm{~g} / \mathrm{L}$ of sodium thiosulfate in a $500 \mathrm{~mL}$ beaker. The solution was stirred at $600 \mathrm{rpm}$ for an additional 5 minutes, then the stirring rate was reduced to $400 \mathrm{rpm}$ for another hour and the polymer was finally allowed to become hydrated for another $24 \mathrm{~h}$ at $200 \mathrm{rpm} .{ }^{16}$ The solution was used as prepared (i.e. not filtered).

Preparation of Borate-Crosslinked HPG Gel: $24 \mathrm{~mL}$ of the 5000 ppm HPG was mixed with $7.5 \mathrm{~mL}$ of diluted EL2X-loaded PEC nanoparticles or an aqueous solution with equivalent concentration of free enzyme in a $40 \mathrm{~mL}$ scintillation vial. $7.5 \mathrm{~mL}$ of a $2000 \mathrm{ppm}$ borax solution was added to the mixture and the $\mathrm{pH}$ was adjusted to 9.2 with $0.1 \mathrm{M} \mathrm{NaOH}$. This yielded a gelant containing approximately 3076 ppm HPG, 385 ppm borax and 0.08\% w/w EL2X). Gel samples were sealed and incubated on a table shaker (LAB-LINE $3520 \mathrm{JR}$, Melrose, IL) at $150 \mathrm{rpm}$ and $40^{\circ} \mathrm{C}$.

\section{Measurement of Viscosity and Viscoelastic Moduli}

HPG Solution: A Bohlin CS-10 rheometer was used with a $40 \mathrm{~mm} / 4^{\circ}$ cone-and-plate geometry to measure the viscosity of HPG solutions. Viscometric assays were performed under a shear rate of $90 \mathrm{~s}^{-1}$ at $25{ }^{\circ} \mathrm{C}$ for pectinase or $40{ }^{\circ} \mathrm{C}$ for EL2X. To conduct the assay, $0.5 \mathrm{~g}$ of enzyme solution, nanoparticle suspension or supernatant was added to $2.0 \mathrm{~g}$ of $5000 \mathrm{ppm}$ HPG solution. After mixing, $1.5 \mathrm{~mL}$ of the solution was removed for viscosity measurements.

Gelled HPG: A Bohlin CS-10 rheometer was used to measure the elastic ( $\left.G^{\prime}\right)$ and viscous ( $G^{\prime \prime}$ ) moduli for $30 \mathrm{~mL}$ gel samples over time at a frequency of $0.5 \mathrm{~Hz}$, strain of $0.1 \mathrm{~Pa}$, and initial stress of 0.1 $\mathrm{Pa}$ in "auto-stress" mode. The double-gap configuration of Couette geometry was used to measure G' and $\mathrm{G}^{\prime \prime}$.

\section{Results and Discussion}

\section{Characterization of Enzymes}

Activity was measured by viscometric assay for the two enzymes at different $\mathrm{pH}$ and temperature (Figures 1 and 2) to identify optimal conditions for each. In contrast to pectinase, The commercial product, EL2X, showed significant activity at $\mathrm{pH}$ 9, consistent with its intended use at higher temperatures and $\mathrm{pH}$, with activity claimed in the product data sheet of $50-160^{\circ} \mathrm{F}\left(10-71^{\circ} \mathrm{C}\right)$ or up to $\mathrm{pH} 10 .^{17}$ 
Barati, R., Johnson, S. J., McCool, S., Green, D. W., Willhite, G. P. and Liang, J.-T. (2012), Polyelectrolyte complex nanoparticles for protection and delayed release of enzymes in alkaline $\mathrm{pH}$ and at elevated temperature during hydraulic fracturing of oil wells. J. Appl. Polym. Sci.. Publisher's official version: <http://dx.doi.org10.1002/app.36845>. Open Access version: http://kuscholarworks.ku.edu/dspace/.

\section{Characterization and Optimization of Enzyme-Loaded PEC Nanoparticles}

Triplicates of several formulations varying in enzyme concentration and in the order of reagent addition were prepared as shown in Table 1 . Size and zeta potential of the nanoparticles were measured over a range of $\mathrm{pH}$ (6.0-9.5) and are shown in Figures 3 and 4. Zeta potential of the pectinase-loaded nanoparticles (PEC $A^{\prime}$ ) decreased with increasing $\mathrm{pH}$ in the range tested, while particle size showed a maximum near $\mathrm{pH} 7$ then decreased with further increase in $\mathrm{pH}$. Both particle size and zeta potential of the EL2X-loaded PECs decreased with increasing $\mathrm{pH}$.

This is not unexpected since the charge on the PEI is dependent on $\mathrm{pH}$. PEI is a weak base with an isoelectric point $\left(I_{p}\right)$ at $\mathrm{pH} 10.8 .{ }^{18}$ At the $I_{p}, P E I$ is uncharged and forms compact coils. As $p H$ is decreased, more and more secondary amine groups are neutralized to $-\mathrm{NH}^{+}$-; this increases the charge density on the PEI and electrostatic repulsion causes the polymer chains to adopt a more extended configuration, increasing the availability of the charged amine groups to interact with negative charges on the DS or enzyme. Conversely, as $\mathrm{pH}$ increases and approaches the $I_{\mathrm{p}}$, the PEI becomes less charged and more condensed, causing a reduction in magnitude of the net positive charge in the particles, resulting in less repulsion between $\mathrm{PEI}$ chains within each particle and hence decreased particle size.

Order of mixing had a profound effect on particle formation and enzyme entrapment efficiency, with best results seen when enzyme was mixed with the PEI before the addition of DS (formulations designated by a prime (') symbol). This contrasts with previous experiences with $\mathrm{Cr}(\mathrm{III})$ as the entrapped material, where order of mixing did not have a significant effect. The difference is almost certainly due to the inability of the high Mw enzymes to be intercalated into preformed PEI-DS particles, unlike the much smaller chromium atoms. Only enzyme formulations assembled in this order were considered further.

To measure enzyme activity and entrapment efficiency, viscometric assay was performed on nanoparticle suspensions, supernatants and enzymes as described above. Entrapment efficiency $\left(\mathrm{EE}_{\mathrm{A}}\right)$ of the pectinase-loaded nanoparticles (PEC $A^{\prime}$ ) was $91 \%$ at $\mathrm{pH} 8.5$. EL2X systems showed $\mathrm{EE}_{\mathrm{A}}$ of $46 \%$ when $0.1 \mathrm{~mL}$ of $100 \%$ EL2X was added (PEC H'), suggesting that the loading capacity of the PEC system had been exceeded. Since PEC formation only occurs at low polyelectrolyte concentrations, the amount of EL2X was reduced to $0.5 \mathrm{~mL}\left(\mathrm{I}^{\prime}\right)$ and $0.025 \mathrm{~mL}\left(\mathrm{~J}^{\prime}\right), \mathrm{EE}_{\mathrm{A}}$ was slightly improved to about $54 \%$ and $61 \%$ respectively (Figure 5). Decreasing the loading of EL2X also decreased the particle size for the EL2Xloaded systems (Figure 4).

\section{Degradation of Borate Cross-Linked HPG gels by EL2X-loaded Nanoparticles at $40{ }^{\circ} \mathrm{C}$}

Viscosity is commonly measured during field application since it is a relatively simple and fast assay. In order to further characterize the degradation process, a rheometric study was also performed. Delayed release of pectinase using system $\mathrm{A}$ with $\mathrm{pH}$ of 8.7 at $25{ }^{\circ} \mathrm{C}$ had been demonstrated previously. ${ }^{10}$ In this work we investigate delayed release of EL2X from the $\mathrm{H}^{\prime} \mathrm{PEC}$ system at pH $9.4(\mathrm{EE}=$ $54 \%)$ and $40^{\circ} \mathrm{C}$. 
Barati, R., Johnson, S. J., McCool, S., Green, D. W., Willhite, G. P. and Liang, J.-T. (2012), Polyelectrolyte complex nanoparticles for protection and delayed release of enzymes in alkaline $\mathrm{pH}$ and at elevated temperature during hydraulic fracturing of oil wells. J. Appl. Polym. Sci.. Publisher's official version: <http://dx.doi.org10.1002/app.36845>. Open Access version: http://kuscholarworks.ku.edu/dspace/.

EL2X-loaded nanoparticles (PEC J') with final EL2X concentration of $0.4 \%$ were mixed with $5000 \mathrm{ppm}$ HPG solution in $2 \% \mathrm{KCl}$ and $2000 \mathrm{ppm}$ borax cross-linker was added. The mixture gelled immediately upon addition of the borax at room temperature. Gels with enzymes and control gels without enzyme added were shaken at $150 \mathrm{rpm}$ and $40^{\circ} \mathrm{C}$; samples were removed at intervals and viscoelastic moduli were measured using a Bohlin rheometer. Elastic $\left(G^{\prime}\right)$ and viscous $\left(G^{\prime \prime}\right)$ moduli were plotted versus time for a frequency of $0.5 \mathrm{~Hz}$ (Figure 6). Delay in degradation of both moduli was observed; $\mathrm{G}^{\prime}$ and $\mathrm{G}^{\prime \prime}$ reached values equal to or lower than those of an equivalent HPG gel degraded with unentrapped enzyme in $7 \mathrm{~h}$ and $11 \mathrm{~h}$ respectively, indicating a significant delay in activity of enzyme (by 4 and $5 \mathrm{~h}$ ). Plots of both $\mathrm{G}^{\prime}$ and $\mathrm{G}^{\prime \prime}$ were shifted towards longer delays for the systems degraded with nanoparticles compared to the systems degraded with unentrapped enzyme, indicating a delay in transition from gel to a low viscosity solution. Faster decline of $\mathrm{G}^{\prime}$ compared to $\mathrm{G}^{\prime \prime}$ is typical for enzymatic degradation of guar solutions since the gel structure is attacked first, followed by the degradation of the guar back bone. $^{19}$

\section{Protective Effect of Nanoparticles on Enzymes}

Viscometric assays were performed for pectinase and EL2X enzymes at $\mathrm{pH}$ values of 9.1 and 9.75 and temperatures of $40{ }^{\circ} \mathrm{C}$ and $50^{\circ} \mathrm{C}$ respectively. Both enzymes are rapidly denatured under these conditions. The assay was repeated three times and a representative plot of viscosity versus time is shown in Figure 7. The enzymes retained their activities for a significantly longer time under similar conditions after being entrapped by the PEC nanoparticles. It would appear that entrapment of enzymes within the nanoparticles confers protection from the $\mathrm{pH}$ of the bulk solution, presumably by a local buffering effect by the PEI, which dominates the $\mathrm{pH}$ of the nanoparticle preparations (8.3 for PEC $\mathrm{A}^{\prime}$ and 9.3 for PEC I').

This is consistent with the protective effects of PEC nanoparticles reported for several drugs and proteins. $^{9,20}$

\section{Conclusions}

Enzymes entrapped in PEC nanoparticles optimized for maximum enzyme entrapment efficiency are able to break borate-crosslinked HPG gel, with the action being delayed significantly compared to unentrapped enzymes at the same concentration. The delayed release of the enzyme allows the loaded particles to be mixed with the gelant with a reduced risk of failure to gel or premature breaking. Polyelectrolyte complex entrapment of gel-breaking enzymes shows potential for improving the performance of hydraulic fracturing treatments in conventional oil and gas reservoirs.

Pectinase is inactivated rapidly at pH 9.1 and $40{ }^{\circ} \mathrm{C}$ and the commercial enzyme mixture (EL2X) at pH 9.75 and 50 으. Enzyme activity observed in PEC preparations under these conditions suggest that PEC entrapment provides a protective environment for both enzymes and this may allow application in conditions which were previously untenable. 
Barati, R., Johnson, S. J., McCool, S., Green, D. W., Willhite, G. P. and Liang, J.-T. (2012), Polyelectrolyte complex nanoparticles for protection and delayed release of enzymes in alkaline $\mathrm{pH}$ and at elevated temperature during hydraulic fracturing of oil wells. J. Appl. Polym. Sci.. Publisher's official version: <http://dx.doi.org10.1002/app.36845>. Open Access version: http://kuscholarworks.ku.edu/dspace/.

\section{References}

1. $\quad$ Economides, M. J.; Nolte, K. G., Reservoir Stimulation. 3rd ed.; John Wiley \& Sons, Inc.: New York \& Chichester, 2000.

2. Palisch, T. T.; Vincent, M. C.; Handren, P. J., Slickwater fracturing - food for thought. SPE Production and Operations 2010, 25 (3), 327-344.

3. Armstrong, C. D.; Stevens, R. F.; Lee, H.; Stephenson, C.; Qu, Q., The next generation of regenerative catalytic breakers for use in alkaline and high-temperature fracturing fluids. In Society of Petroleum Engineers International Symposium and Exhibition on Formation Damage Control, Lafayette, LA, 2010.

4. Fodge, D. W.; Anderson, D. M.; Pettey, T. M. Hemicellulase Active at Extremes of pH and Temperature and Utilizing the Enzyme in Oil Wells. US Patent 5,551,515, Sep. 31996.

5. Tjon-Joe-Pin, R. M. Enzyme Breaker For Galactomannan Based Fracturing Fluid. US Patent 5201370, April 13, 1993.

6. Ayoub, J. A.; Hutchins, R. E.; Van der Bas, F.; Cobianco, S.; Emiliani, C. N.; Glover, M.; Kohler, M.; Marino, S.; Nitters, G.; Norman, D.; Turk, G., New findings in fracture cleanup change industry perceptions. In Society of Petroleum Engineers International Symposium and Exhibition on Formation Damage Control, Lafayette, LA, 2006.

7. Tiyaboonchai, W. Development of a New Nanoparticle Delivery Vehicle Based on An Aqueous Polymer System: Polyethylenimine and Dextran Sulfate. The University of Kansas, Lawrence, KS, 2003.

8. Tiyaboonchai, W.; Woiszwillo, J.; Middaugh, C. R., Formulation and characterization of DNApolyethylenimine-dextran sulfate nanoparticles. European Journal of Pharmaceutical Sciences 2003, 19, 191-202.

9. Tiyaboonchai, W.; Woiszwillo, J.; Sims, R. C.; Middaugh, C. R., Insulin containing polyethylenimine-dextran sulfate nanoparticles. International Journal of Pharmaceutics 2003, 225, 139151.

10. Barati, R.; Johnson, S. J.; McCool, S.; Green, D. W.; Willhite, G. P.; Liang, J.-T., Fracturing fluid cleanup by controlled release of enzymes from polyelectrolyte complex nanoparticles. Journal of Applied Polymer Science 2011, 121 (3), 1292-1298.

11. Cordova, M.; Cheng, M.; Trejo, J.; Johnson, S. J.; Willhite, G. P.; Liang, J.-T.; Berkland, C., Delayed HPAM gelation via transient sequestration of chromium in polyelectrolyte complex nanoparticles.

Macromolecules 2008, 41 (12), 4398-4404. 
Barati, R., Johnson, S. J., McCool, S., Green, D. W., Willhite, G. P. and Liang, J.-T. (2012), Polyelectrolyte complex nanoparticles for protection and delayed release of enzymes in alkaline $\mathrm{pH}$ and at elevated temperature during hydraulic fracturing of oil wells. J. Appl. Polym. Sci.. Publisher's official version: <http://dx.doi.org10.1002/app.36845>. Open Access version: http://kuscholarworks.ku.edu/dspace/.

12. Berkland, C.; Cordova, M.; Liang, J.-T.; Willhite, G. P. Polyelectrolyte Complexes For Oil and Gas Applications. US Patent WO 2008/030758 A1, 13 March 2008.

13. Koetz, J.; Kosmella, S., Polyelectrolytes and Nanoparticles. Springer-Verlag: Berlin, 2007; p 105.

14. Hunter, R. J., Zeta Potential in Colloid Science: Principles and Applications. Academic Press: Waltham, MA, 1981; p 386.

15. Bell, T. A.; Etchells, J. L. A Method for Testing Cucumber Salt-Stock Brine for Softening Activity; Agricultural Research Service, US Department of Agriculture: Washington, DC, 1955.

16. Tayal, A.; Kelly, R. M.; Khan, S. A., Rheology and molecular weight changes during enzymatic degradation of water-soluble polymer. Macromolecules 1999, 32, 294-300.

17. Anonymous, Product Data Sheet for ECONO GelBreak-EL2X. Economy Polymers and Chemicals: Houston, TX, 2000.

18. Hostetler, R. E.; Swanson, J. W., Diffusion into and adsorption of polyethylenimine on porous silica gel. Polymer Chemistry 1974, 12 (1), 29-43.

19. Cheng, Y.; Prud'homme, R. K., Enzymatic degradation of guar and substituted guar. Biomacromolecules 2000, 1, 782-788.

20. Hartig, S. H.; Greene, R. R.; Dikov, M. M.; Prokop, A.; Davidson, M., Multifunctional nanoparticulate polyelectrolyte complexes. Pharmaceutical Research 2007, 24 (12), 2353-2369. 
Barati, R., Johnson, S. J., McCool, S., Green, D. W., Willhite, G. P. and Liang, J.-T. (2012), Polyelectrolyte complex nanoparticles for protection and delayed release of enzymes in alkaline $\mathrm{pH}$ and at elevated temperature during hydraulic fracturing of oil wells. J. Appl. Polym. Sci.. Publisher's official version: <http://dx.doi.org10.1002/app.36845>. Open Access version: http://kuscholarworks.ku.edu/dspace/.

Table 1 Polyelectrolyte complex nanoparticle (PEC) formulations differed in the concentration of enzymes and order of mixing.

\begin{tabular}{|c|c|c|c|c|c|c|}
\hline PEC & $\begin{array}{c}1 \% \text { w/w } \\
\text { PEI(aq), } \\
\mathbf{m L}\end{array}$ & $\begin{array}{c}1 \% \text { w/w } \\
\text { DS(aq), } \mathbf{m L}\end{array}$ & $\begin{array}{c}\mathbf{2 5 \%} \mathbf{w} / \mathbf{w} \\
\begin{array}{c}\text { Pectinase(aq), } \\
\mathbf{m L}\end{array}\end{array}$ & $\begin{array}{c}\text { EL2X } \\
\text { (as supplied), } \\
\mathbf{m L}\end{array}$ & $\begin{array}{c}\text { Make-up } \\
\text { water, } \mathbf{m L}\end{array}$ & Order of Addition \\
\hline $\mathrm{A}$ & 2 & 1 & 0.1 & - & - & PEI, DS, Pectinase \\
\hline $\mathrm{A}^{\prime}$ & 2 & 1 & 0.1 & - & - & PEI, Pectinase, DS \\
\hline $\mathrm{H}$ & 2 & 1 & - & 0.1 & - & PEI, DS, EL2X \\
\hline $\mathrm{H}^{\prime}$ & 2 & 1 & - & 0.1 & - & PEI, EL2X, DS \\
\hline $\mathrm{I}$ & 2 & 1 & - & 0.05 & 0.05 & PEI, DS, EL2X \\
\hline $\mathrm{I}^{\prime}$ & 2 & 1 & - & 0.05 & 0.05 & PEI, EL2X, DS \\
\hline $\mathrm{J}$ & 2 & 1 & - & 0.025 & 0.075 & PEI, DS, EL2X \\
\hline $\mathrm{J}^{\prime}$ & 2 & 1 & - & 0.025 & 0.075 & PEI, EL2X, DS \\
\hline
\end{tabular}


Barati, R., Johnson, S. J., McCool, S., Green, D. W., Willhite, G. P. and Liang, J.-T. (2012), Polyelectrolyte complex nanoparticles for protection and delayed release of enzymes in alkaline $\mathrm{pH}$ and at elevated temperature during hydraulic fracturing of oil wells. J. Appl. Polym. Sci.. Publisher's official version: <http://dx.doi.org10.1002/app.36845>. Open Access version: http://kuscholarworks.ku.edu/dspace/.

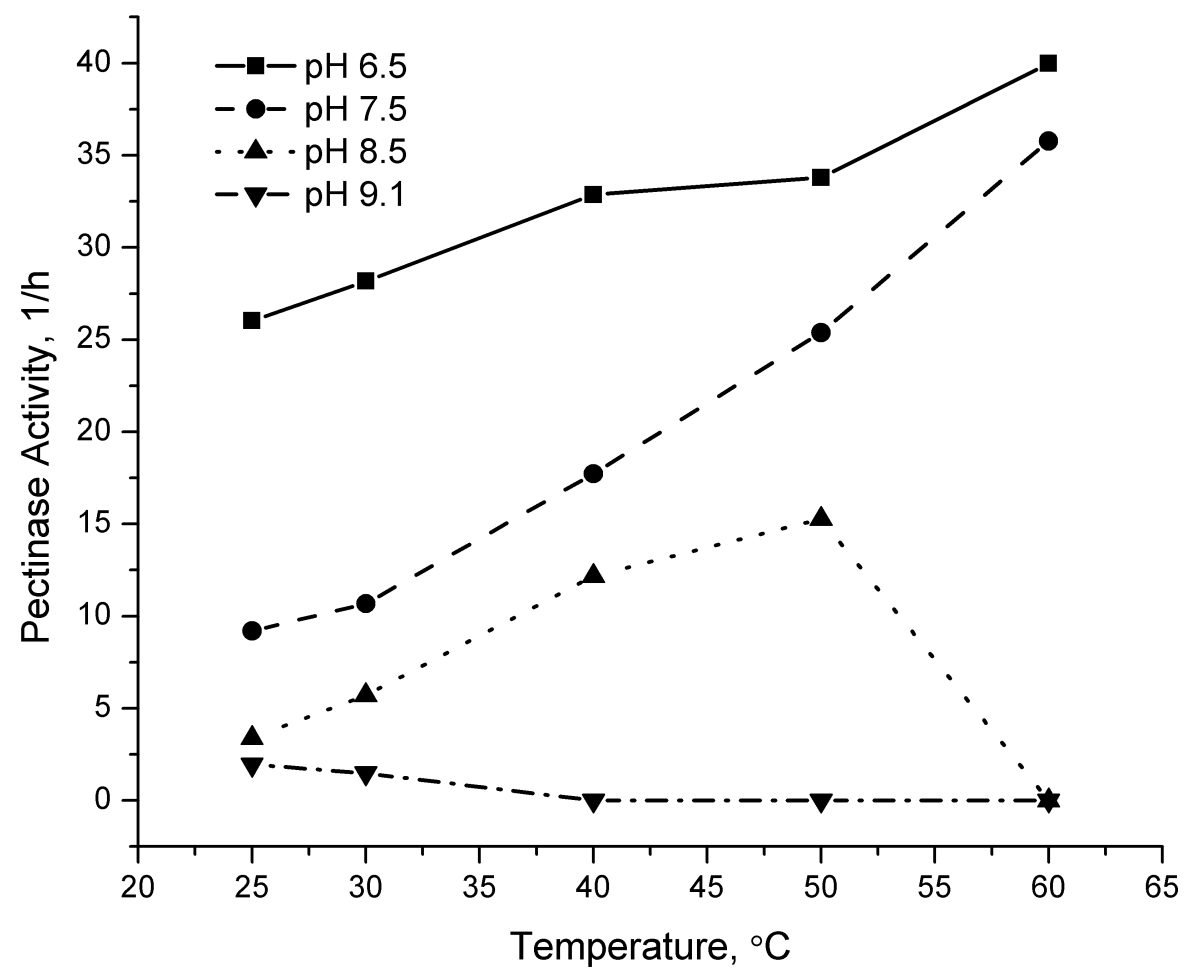

Figure 1 Activity of pectinase vs. temperature at different $\mathrm{pH}$ values. Activity was measured using a viscometric assay for 5000 ppm HPG solutions degraded using $0.02 \%$ pectinase. 
Barati, R., Johnson, S. J., McCool, S., Green, D. W., Willhite, G. P. and Liang, J.-T. (2012), Polyelectrolyte complex nanoparticles for protection and delayed release of enzymes in alkaline $\mathrm{pH}$ and at elevated temperature during hydraulic fracturing of oil wells. J. Appl. Polym. Sci.. Publisher's official version: <http://dx.doi.org10.1002/app.36845>. Open Access version: http://kuscholarworks.ku.edu/dspace/.

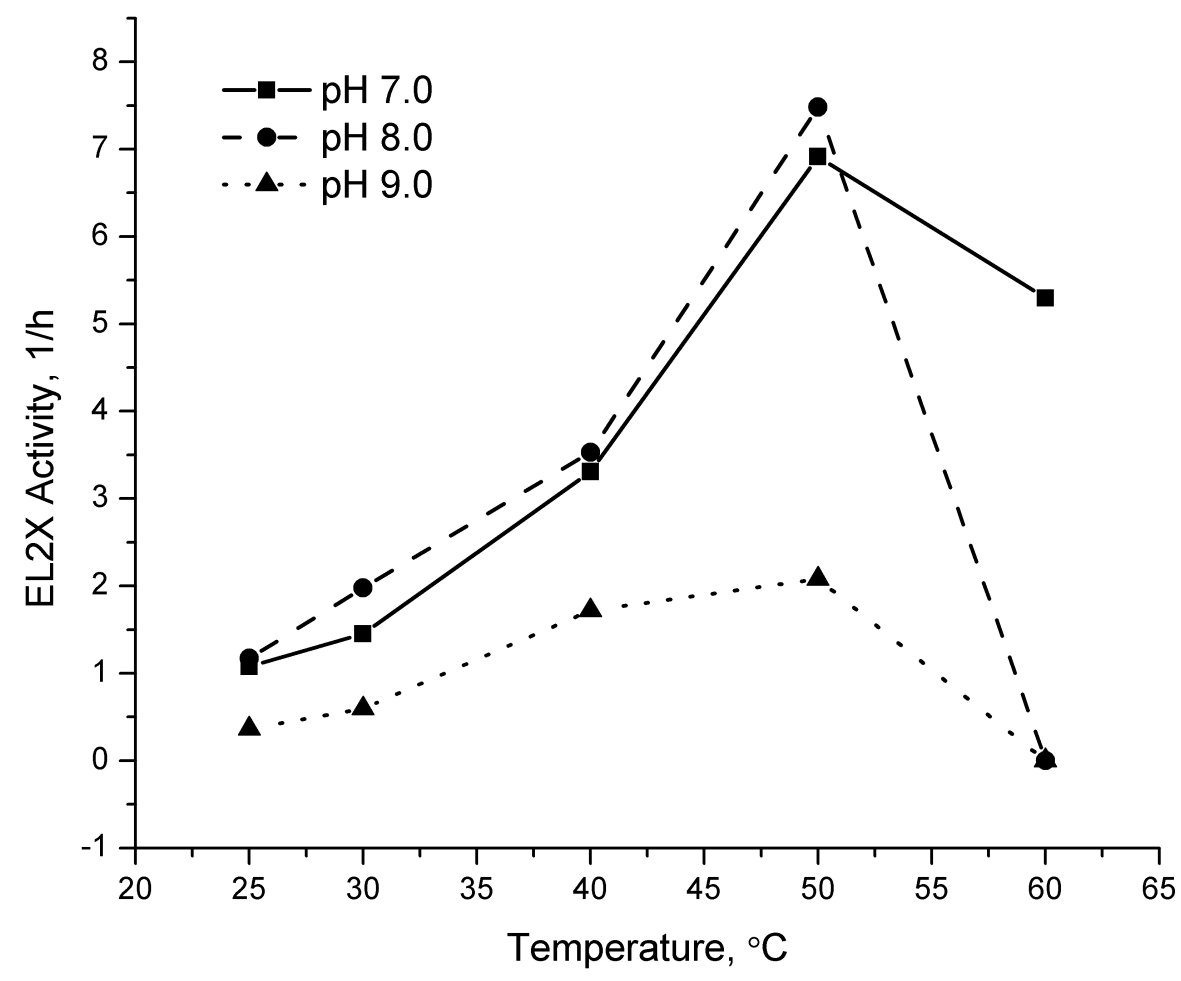

Figure 2 Activity of EL2X vs. temperature at different $\mathrm{pH}$ values. Activity was measured using a viscometric assay for 5000 ppm HPG solutions degraded using $0.08 \%$ EL2X. 
Barati, R., Johnson, S. J., McCool, S., Green, D. W., Willhite, G. P. and Liang, J.-T. (2012), Polyelectrolyte complex nanoparticles for protection and delayed release of enzymes in alkaline $\mathrm{pH}$ and at elevated temperature during hydraulic fracturing of oil wells. J. Appl. Polym. Sci.. Publisher's official version: <http://dx.doi.org10.1002/app.36845>. Open Access version: http://kuscholarworks.ku.edu/dspace/.

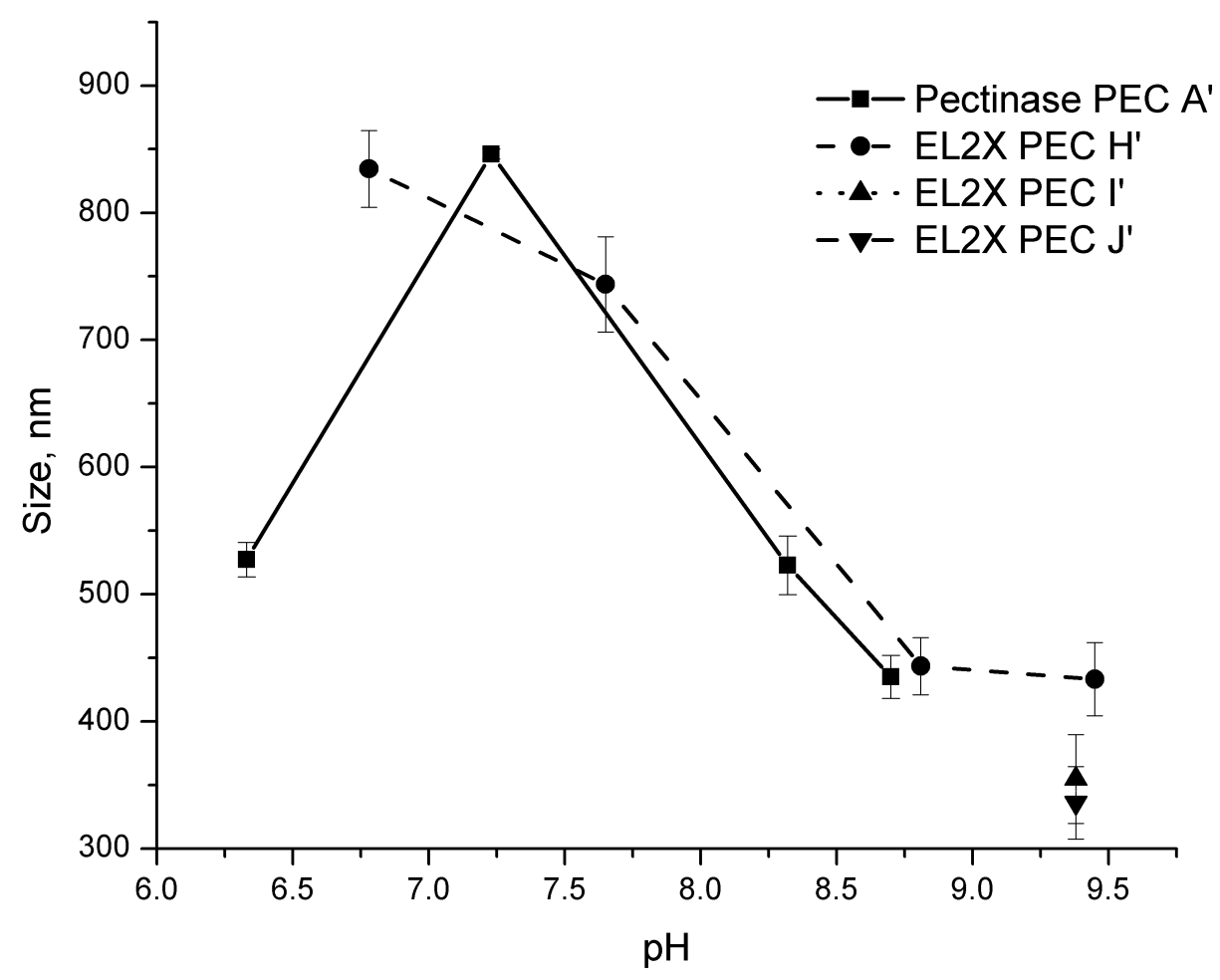

Figure 3 Mean size versus $\mathrm{pH}$ for pectinase $\left(\mathrm{A}^{\prime}\right)$ and EL2X $\left(\mathrm{H}^{\prime}, \mathrm{I}^{\prime}, \mathrm{J}^{\prime}\right)$ loaded PECs. Error bars $=1 \mathrm{SE}, \mathrm{n}=3$. 
Barati, R., Johnson, S. J., McCool, S., Green, D. W., Willhite, G. P. and Liang, J.-T. (2012), Polyelectrolyte complex nanoparticles for protection and delayed release of enzymes in alkaline $\mathrm{pH}$ and at elevated temperature during hydraulic fracturing of oil wells. J. Appl. Polym. Sci.. Publisher's official version: <http://dx.doi.org10.1002/app.36845>. Open Access version: http://kuscholarworks.ku.edu/dspace/.

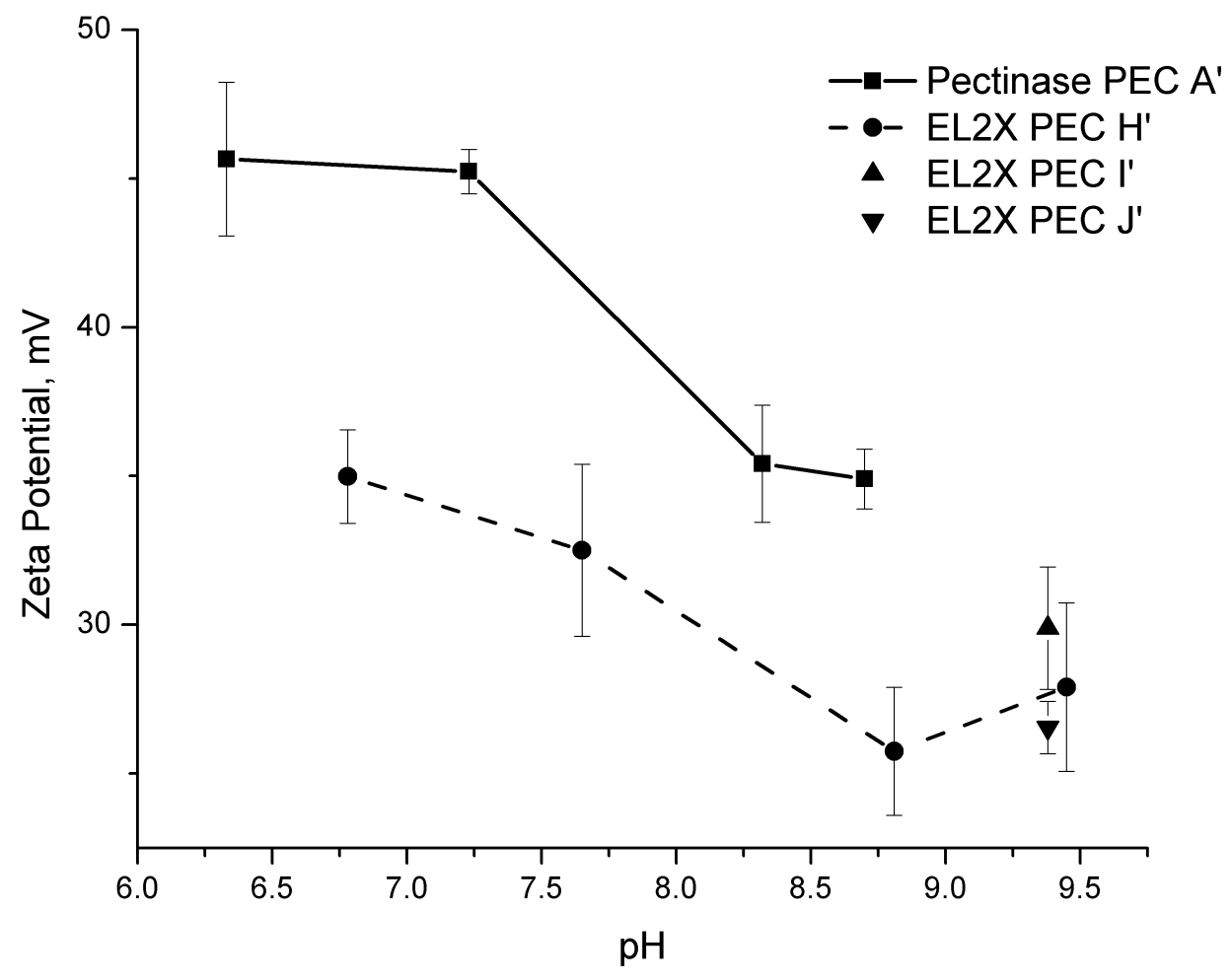

Figure 4 Mean zeta potential versus $\mathrm{pH}$ for pectinase $\left(\mathrm{A}^{\prime}\right)$ and $\mathrm{EL} 2 \mathrm{X}\left(\mathrm{H}^{\prime}, \mathrm{I}^{\prime}, \mathrm{J}^{\prime}\right)$ loaded PECs. Error bars $=1$ $\mathrm{SE}, \mathrm{n}=3$. 
Barati, R., Johnson, S. J., McCool, S., Green, D. W., Willhite, G. P. and Liang, J.-T. (2012), Polyelectrolyte complex nanoparticles for protection and delayed release of enzymes in alkaline $\mathrm{pH}$ and at elevated temperature during hydraulic fracturing of oil wells. J. Appl. Polym. Sci.. Publisher's official version: <http://dx.doi.org10.1002/app.36845>. Open Access version: http://kuscholarworks.ku.edu/dspace/.

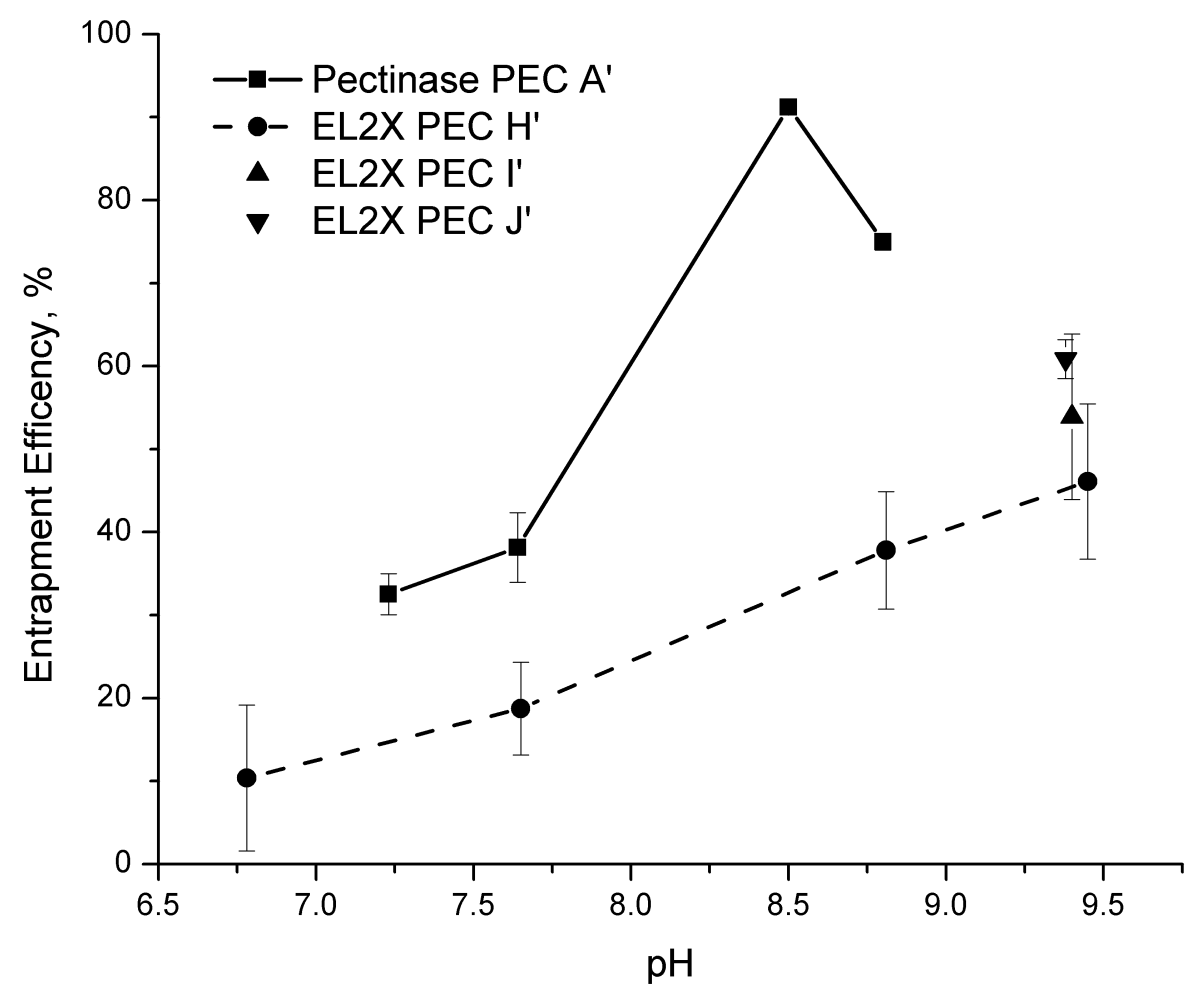

Figure 5 Entrapment efficiency vs. pH for pectinase $\left(A^{\prime}\right)$ and $\operatorname{EL} 2 X\left(H^{\prime}, I^{\prime}, J^{\prime}\right)$ loaded PECs at $25{ }^{\circ} \mathrm{C}$ and 40 ${ }^{\circ} \mathrm{C}$, respectively. Error bars $=1 \mathrm{SE}, \mathrm{n}=3$. 
Barati, R., Johnson, S. J., McCool, S., Green, D. W., Willhite, G. P. and Liang, J.-T. (2012), Polyelectrolyte complex nanoparticles for protection and delayed release of enzymes in alkaline $\mathrm{pH}$ and at elevated temperature during hydraulic fracturing of oil wells. J. Appl. Polym. Sci.. Publisher's official version: <http://dx.doi.org10.1002/app.36845>. Open Access version: http://kuscholarworks.ku.edu/dspace/.

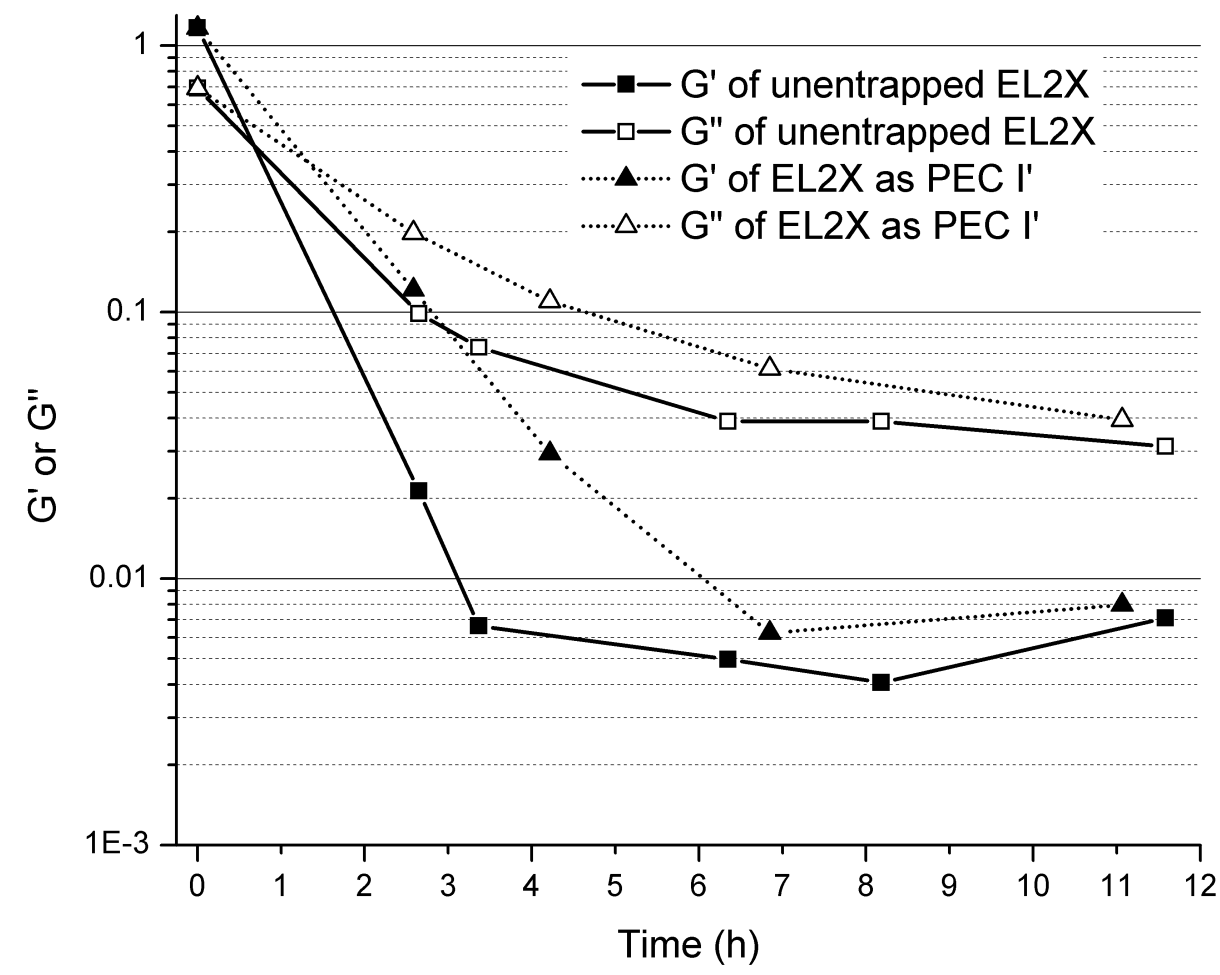

Figure $6 \mathrm{G}^{\prime}$ and $\mathrm{G}^{\prime \prime}$ vs. time for borate-crosslinked HPG gel degraded using either $0.08 \%$ unentrapped EL2X or an equivalent amount of EL2X PECI' (pH 9.2, $\left.40^{\circ} \mathrm{C}\right)$. 
Barati, R., Johnson, S. J., McCool, S., Green, D. W., Willhite, G. P. and Liang, J.-T. (2012), Polyelectrolyte complex nanoparticles for protection and delayed release of enzymes in alkaline $\mathrm{pH}$ and at elevated temperature during hydraulic fracturing of oil wells. J. Appl. Polym. Sci.. Publisher's official version: <http://dx.doi.org10.1002/app.36845>. Open Access version: http://kuscholarworks.ku.edu/dspace/.

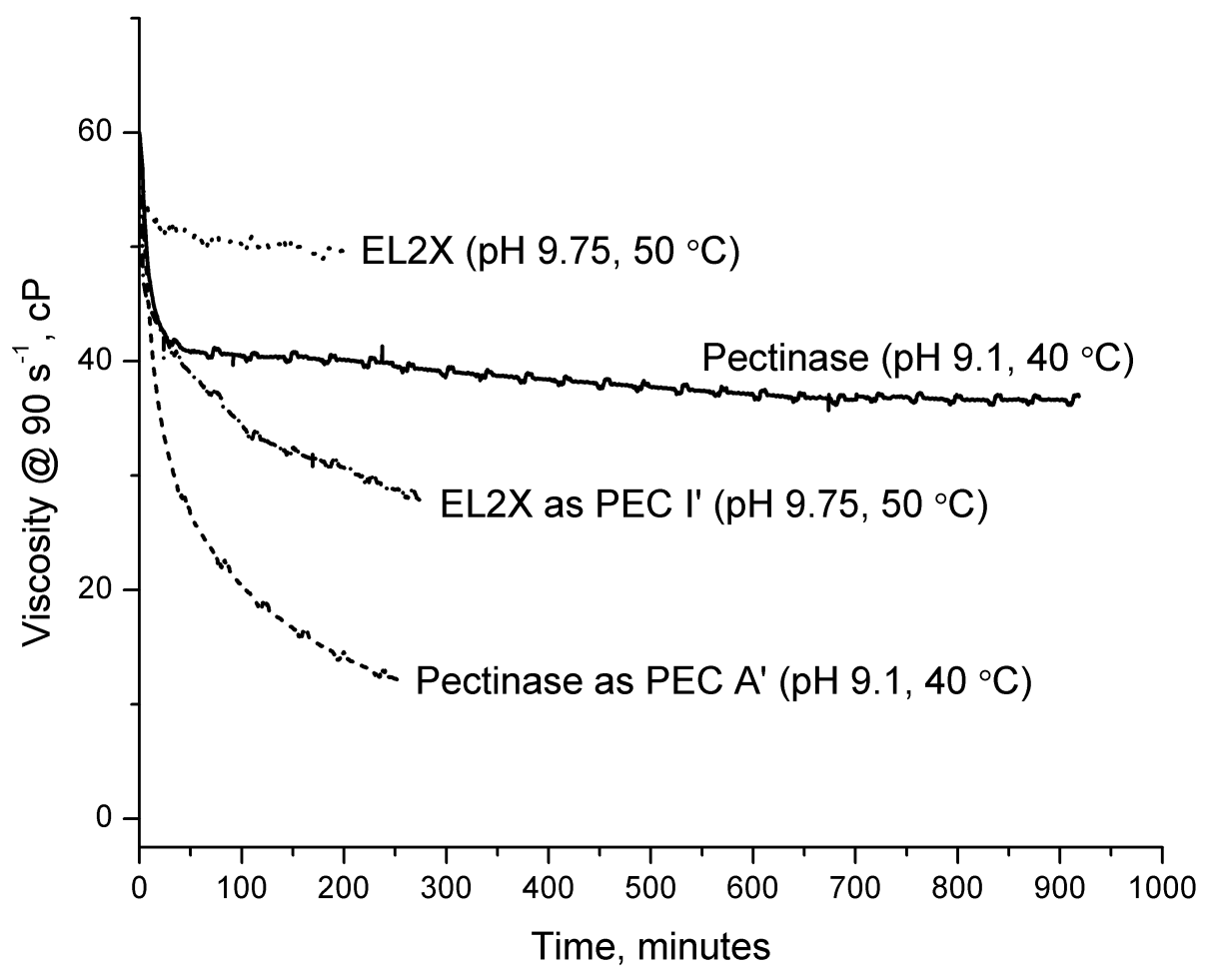

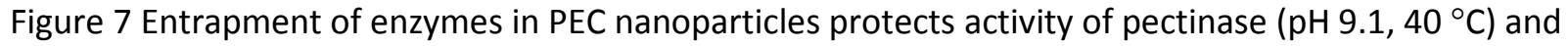
$\operatorname{EL} 2 X\left(\mathrm{pH} 9.75,50^{\circ} \mathrm{C}\right)$. 